\section{GRAIN LEGUME PROTEIN QUALITY: A HOT SUBJECT}

\author{
Maria Carlota Vaz Patto \\ ITQB NOVA \\ cpatto@itqb.unl.pt
}

\section{CALIDAD DE LA PROTEÍNA DE LAS LEGUMINOSAS GRANO: UN TEMA CANDENTE}

Cómo citar este artículo/Citation: Vaz Patto, M. C. (2016). Grain legume protein quality: A hot subject. Arbor, 192 (779): a314. doi: http://dx.doi.org/10.3989/arbor.2016.779n3004
Copyright: (c) 2016 CSIC. Este es un artículo de acceso abierto distribuido bajo los términos de la licencia Creative Commons Attribution (CC BY) España 3.0.

Recibido: 08 marzo 2016. Aceptado: 06 mayo 2016.

\begin{abstract}
Grain legumes, also called pulses, play a key role in the nutritional improvement of food and feed. These legumes are important sources of protein as well as other nutritional compounds. Today, protein is one of the most sought after ingredients in the market and grain legumes represent one of the most sustainable protein sources. However, not all grain legume proteins are nutritionally equal. Their quality varies and depends on their amino acid composition and digestibility. In this article, we review concepts related to grain legume protein quality and discuss challenges regarding their genetic improvement. A comprehensive database of grain legume amino acid profiles and protein digestibility is needed to address the matter of protein quality in grain legume breeding. This database will be enhanced by quantitative information on digestibility-reducing bioactive compounds and the development of reliable screening tools. The achievement of higher protein quality grain legume varieties, better adjusted to animal and human requirements, will cut dietary protein content, associated costs and nitrogen excretion, thus reducing the environmental impact.
\end{abstract}

KEYWORDS: Grain legumes; protein quality; amino acids; digestibility; anti-nutritional factors.
RESUMEN: Las leguminosas grano tienen un alto potencial en alimentación humana y animal siendo una importante fuente de proteínas así como de otros compuestos beneficiosos para la nutrición y salud. La proteína es uno de los ingredientes más demandados y las leguminosas grano son una delas fuentes más sostenible de proteína. Sin embargo, no todas las leguminosas grano son igual de nutritivas, variando la calidad con la composición de aminoácidos y su digestibilidad. En este artículo revisaremos los conceptos de calidad de la proteína y discutiremos las posibilidades de mejora genética. Para abordar con éxito la mejora de la calidad de la proteína será de gran ayuda disponer de bases de datos con los perfiles de aminoácidos y de digestibilidad, así como de información cuantitativa sobre los compuestos bioactivos que reducen la digestibilidad, todo ello unido a métodos fiables para su evaluación. El desarrollo de variedades de leguminosas con una proteína de mayor calidad, más ajustadas a las necesidades tanto humanas como del ganado, permitirá una mayor eficiencia nutritiva, reduciendo el contenido de proteína en la dieta y los costes asociados, así como la excreción de nitrógeno, disminuyendo el impacto medioambiental.

PALABRAS CLAVE: Leguminosas grano; calidad de la proteína; aminoácidos; digestibilidad; factores anti nutritivos 


\section{GRAIN LEGUME PROTEINS ARE NOT ALL NUTRITIO- NALLY EQUAL}

Protein remains one of the hottest ingredients that consumers are seeking in the market, and many challenges exist when determining the best protein source for a particular purpose. The relative ranking of protein sources in terms of quality will directly impact the commercial value of a protein product.

Grain legumes, also called pulses, are environmentally friendly sustainable sources of proteins, besides having many other nutritional and health beneficial components.

Grain legumes high amounts of protein range from $20 \%$ in pea to $38-40 \%$ in lupins (Boye, Zare, and Pletch, 2010; Rumiyati, James and Jayasena, 2012). The main protein fractions in grain legumes are the salt soluble globulins (legumin and vicilin) or storage proteins, and albumins (that include many "housekeeping" proteins, protease inhibitors, and lectins). Prolamins and glutelins are very scarce or absent. In general these proteins are characterized by high lysine (Lys) content and a relative deficiency in sulphur amino acids (methionine - Met and cysteine - Cys) and tryptophan (Trp) (Wang, Domoney, Hedley, Casey and Grusak, 2003). This is explained by the amino acid composition of the main storage proteins globulins, whose sulphur amino acid content is low (especially for the vicilin fraction) whereas Lys content is high (Gatel, 1994). Indeed considering the protein amino acid profile, cereal and grain legumes appear nutritionally complementary: those amino acids deficient in one (Lys in cereals and sulphur amino acids in grain legumes) are adequate in the other. Nevertheless the relative Trp deficiency in grain legumes is more of a problem because natural sources are rather scarce and synthetic Trp is expensive (Gatel, 1994).

Proteins are important components of human and animal diets and play an essential role as structural and functional components of living systems. As human and animal bodies are incapable of maintaining reserves of protein, a constant supply of good quality protein is needed to maintain growth and other physiological functions (Boye et al., 2010). Additionally protein quality is becoming increasingly important due to the need to optimally match food (and feed) supply and human (or animal) protein needs, against the backdrop of a rapid growing world population and limited natural resources (FAO, 2013). The need for more efficient land and water use, as well as a reduction of greenhouse gas emissions make it necessary to rethink protein sources. With the growing demand for protein around the world, high quality, low cost, and environmental sustainable grain legume alternatives are necessary.

However grain legume proteins are not all nutritionally equal and quality varies both between and within species. This can partly be explained by the variability existing at the individual amino acids composition and their bioavailability (the fraction potentially available for further uptake and absorption) (Messad, Létourneau-Montminy, Charbonneau, Sauvant and Guay, 2015). "High quality proteins" are those that are readily digestible and contain the dietary essential (indispensable) amino acids in quantities that correspond to human/animal requirements. The typical presence of secondary plant metabolites also referred as anti-nutritional factors (ANF) or bioactive compounds in grain legume seeds, reduce protein digestibility (Gilani, Xiao and Cockell, 2012), restricting their use especially in animal feeding. On the other hand, their low content in sulphur containing amino acids and Trp require some type of supplementation. This is especially restrictive in the case of organic farming where supplementation with higher quality protein processed oilseed products subjected to solvent extraction processes (as can be the case of soybean meal), or with crystalline amino acids (IFOAM, 2014) is not accepted.

\section{HOW CAN WE MEASURE PROTEIN QUALITY?}

Protein quality evaluation measures the proportion of amino acids that can be absorbed from the diet and utilized in the body. It is a relative measure that aims to predict the capacity of food protein sources and diets to satisfy the body's demand for amino acids and nitrogen (WHO, 2007).

Determining protein quality is important both in food sciences and animal feeding. Although the motivation for obtaining suitable information is different, the overall aim of matching food resources most effectively to nutrient needs is the same. As an example, adequate high quality protein intake is essential for athletes to maintain optimal muscle mass and maximize their performance. Additionally, high quality protein is recommended to improve body weight management and to help to maintain muscle functionality in older people (Devries and Philips, 2015). Protein is also the key component and the most expensive macronutrient in the diet of any farmed animal, making the accurate assessment of protein utilization critically important. 
Adjusting the protein supply to better meet the requirements of each animal or person through knowledge of protein quality levels can helpfully reduce dietary protein content. It can also reduce environmental pollution by helping reduce the amount of fecal nitrogen. Nutrient utilization can also be made more efficient. Increased growth in farm animals is another positive impact of protein supply adjustment. Finally, there are important implications for preventing both chronic and infectious diseases, maximizing growth and optimizing health in humans.

A number of methods currently exist to evaluate protein quality in human nutrition. While these have some limitations, they include the consideration of amino acid composition, the digestibility of the protein and the bioavailability of individual amino acids (Boye et al., 2010).

There is no direct method for measuring bioavailability, but the greatest source of variation in bioavailability is, in most cases, digestibility. It is therefore generally estimated using measures of in vivo digestibility.

The Protein Digestibility Corrected Amino Acid Score (PDCAAS) was the method adopted in 1991 to describe dietary protein quality and has been widely accepted (FAO, 2013). It relies on determination of protein content, amino acids profiles and protein digestibility. However there were a number of concerns with regards to this tool, such as overestimation of the quality of proteins containing anti-nutritional factors.

As already mentioned, the food matrix (e.g. content of dietary fibre or ANF/bioactive compounds such as polyphenols or trypsin inhibitors commonly found in grain legumes) affects both digestibility and bioavailability. Therefore these components must be also taken into consideration when evaluating protein quality of such matrixes (Gilani et al., 2012). The impact of some of these ANF may be removed by processing. However, when grain legumes are consumed raw (animal feed), they can cause substantial reductions in protein quality. As an example the presence of high levels of trypsin inhibitors in common bean or the presence of high levels of tannins in faba beans caused substantial reductions in protein and amino acids digestibility (up to 50\%) in rats and pigs (Gilani et al., 2012).

In 2013 an expert consultation group from FAO recommended that the more accurate Digestible Indispensable Amino Acid Score (DIAAS) be adopted to replace PDCAAS. It considered for instance each dietary amino acid as an individual nutrient. It also considered ileal amino acid digestibility instead of fecal protein digestibility.
One of the present challenges with this tool is the use of methods to determine true ileal digestibility that normally involve demanding, expensive and ethical complex human and/or animal testing. In the interim, promising in vitro methods that accurately estimate true protein digestibility may be used for rapid routine assessment of legume protein quality, supported by established protein standardized ileal digestibility values of well-defined foods from published data bases (Messad et al., 2015). While it is not realistic to expect absolute agreement between in vivo and in vitro observations, in vitro assays can be a useful tool to rank food proteins according to their protein digestibility (Butts, Monro and Moughan, 2012), and that could be refined by extra information on the presence of compounds affecting digestibility such as ANF.

Currently, improving protein content has been the major breeding target for grain legume breeders, with the enhancement of protein quality only of secondary interest (Schumacher et al., 2011). In addition it appears that any increase in grain legume crude protein content may lead to a decrease of protein quality in terms of amino acid profiles (Gatel, 1994). Nevertheless protein quality improvement is gaining ground among legume breeders.

\section{CAN WE BREED FOR IMPROVED GRAIN LEGUME PROTEIN QUALITY?}

Grain legume species such as peas and faba beans are valuable sources of protein and energy for humans and animals. However they are sometimes low in Met, Cys and Trp content and the presence of secondary plant metabolites (ANF, reducing nutrients digestibility) restricts their protein quality, especially for animal feeding. It is therefore crucial to develop suitable alternatives to meet animal and human protein quality requirements. Breeding for higher protein quality grain legume varieties (in terms of improved amino acid composition and digestibility) would be the most sustainable alternative.

The typical grain legume protein deficiency in sulphur containing amino acids can be overcome in feed production by mixing with cereal protein (with a complementary amino acid composition) or by adding costly synthetic amino acids. Nevertheless, this is still regarded as a target for breeding through the use of natural variation or genetic manipulation (Wang et al., 2003). Taking into account the large variation of the albumin to globulin and the vicilin to legumin ratios among grain legumes and the different amino acid profiles of these various protein fractions, this 
variability could be used to genetically improve their amino acid profiles (Gatel, 1994). However genetic approaches have resulted in relatively limited success. This is mostly due to limited availability of genetic resources for plant breeding, and the fact that genetic traits for high contents of Lys, Trp or Met are generally associated with abnormal plant growth because these traits do not operate in a seed specific manner (Ufaz and Galili, 2008). In contrast results from genetic engineering appear to be more promising. Successful examples of improving the amino acid balance include high-Lys (Falco et al., 1995) or high Met and Cys soybean (Dinkins et al., 2001).

While processing using heat treatments may increase protein digestibility by inactivating or reducing some of the present ANF (Gatel, 1994), this might not always be cost efficient. In contrast to breeding for improved amino acid balance, breeding for improved digestibility by reducing the amounts of ANF is much more promising due to the known natural variation within grain legume species. Indeed recent progress in plant breeding has contributed to the improvement of pulses nutritive value through reductions in digestibility interfering ANF content. Examples are the development of zero-tannin faba bean cultivars (Crepon et al., 2010), the low trypsin inhibitor soybean cultivars (Clarke and Wiseman, 2000) or the low phytate pea cultivars (Warkentin et al., 2012).

Moreover breeding for improved quality in grain legumes is a complex task due to high trait interaction, which often causes quality concerns (Vaz Patto et al., 2015). And protein quality is not an exception. In grain legumes some of the components that may act as anti-nutrients (oligosaccharides, lectins, saponins, phytic acid, phenolic compounds) may also be health-promoting agents preventing chronic diseases (Arnoldi, Zanonia, Lammia and Boschina, 2015) or reduce the risk of bloat in ruminants (Phelan et al., 2015). As an example tannins have shown antioxidant, as well as antimicrobial properties, and some trypsin inhibitors have been shown to function as therapeutic agents against cancer (Boye et al., 2010). Some of these compounds may also alter bitterness or astringency, affecting food taste (Vaz Patto et al., 2015) or are associated with resistance to pests and abiotic stresses (Islam, Rengifo, Redden, Basford and Beebe, 2003; Winkel-Shirley, 2002) making their manipulation by genetic breeding very complex. So while breeding would improve legume nutritional quality, by inactivating or reducing some of the ANF, it may also be desirable to retain some of these ANF for their bioactive properties or their role in defense against insect attacks (Wang et al., 2003).

The absence of appropriate, efficient breeding tools to select for these complex interacting traits has hampered their breeding exploitation (Vaz Patto et al., 2015).

As with grain legume quality improvement in general, a multidisciplinary approach, integrating a comprehensive characterization of the different traits influencing quality, in representative collections of the different grain legume species, will be essential for devising a strategy for protein quality breeding (Vaz Patto et al., 2015). This would lead to the recognition of existing higher protein quality grain legumes and to the development of new environmentally sustainable varieties. Indeed FAO (2013) has recommended as important to plant breeding, and related to sustainability issues, the generation of data at the level of the genetic resource (i.e., biodiversity characterization) on amino acid composition and digestibility. One of the proposed outcomes of the present 2016 International Year of Pulses is such a comprehensive catalogue.

\section{THE FUTURE: GRAIN LEGUME PROTEIN QUALITY SURVEY AT GLOBAL LEVEL AND THE DEVELOPMENT OF RELIABLE AND QUICK SCREENING ASSAYS}

A key message of the 2016 International Year of Pulses is that grain legumes are highly nutritious. But in order to better promote the production and consumption of grain legumes, we must first know the nutritional make-up of these crops so we can appreciate their nutritional benefits. However, no comprehensive, global resource on the composition of grain legumes currently exists. To address this knowledge gap, FAO is working to develop a Global Food Composition Database for grain legumes (IYoP, 2016). Data will be collected from published and unpublished literature with special emphasis on biodiversity and their relation to agriculture and processing features. This database will be a repository of existing analytical data taken from scientific articles and other sources such as unpublished laboratory reports and have a user-friendly interface showing the complete nutrient profile of different types of grain legumes. To add value to such an effort we believe that, besides amino acid composition, available digestibility values and ANFs content should also be included in such a database. This would transform such a database into the perfect gateway tool for any grain legume protein quality improvement program. 
Amino acids composition and digestibility related measurements are often time consuming and expensive to perform in a big number of accessions such as the ones normally involved in breeding programs. The development of accurate, reliable and efficient screening tools on protein content and quality will allow greater possibilities of breeding legume varieties with increased nutritional value as outstanding higher quality accessions would be easily identified. These tools would also help reveal existing genetic diversity needed for improvement. Spectroscopy techniques, such as NIR (Near Infra-Red) or FT-IR (Fourier Transform Infra-Red), have been applied successfully in the measurement of several biomolecules or properties in different agricultural products, with minimal or no sample preparation (Cozzolino, 2015). Examples of such tools are beginning to be used to predict legume protein amino acid composi-

\section{ACKNOWLEDGEMENTS}

The author would like to acknowledge KP Colleary, Ed. D. for the English revision of this manuscript, and the financial support from the European Community's Seventh Framework Program (FP7 / 2007-2013), under the grant agreement no FP7-613551, LEGATO project.

\section{REFERENCES}

Arnoldi, A., Zanonia, C., Lammia, C. and Boschina, G. (2015). The role of grain legumes in the prevention of hypercholesterolemia and hypertension. Critical Reviews in Plant Sciences, 34, pp. 144168. doi:10.1080/07352689.2014.897908

Boye, J., Zare, F. and Pletch, A. (2010). Pulse proteins: Processing, characterization, functional properties and applications in food and feed. Food Research International, 43, pp. 414-431. doi:10.1016/j.foodres.2009.09.003

Boye, J., Wijesinha-Bettoni, R. and Burlingame, B. (2012). Protein quality evaluation twenty years after the introduction of the protein digestibility corrected amino acid score method. British Journal of Nutrition, 108, pp. S183-S211. doi:10.1017/ S0007114512002309

Butts, C. A., Monro, J. A. and Moughan, P. J. (2012). In vitro determination of dietary protein and amino acid digestibility for humans. British Journal of Nutrition, 108, pp. S282-S287. doi:10.1017/S0007114512002310

Carbonaro, M., Maselli, P. and Nucara, A. (2012). Relationship between digestibility and secondary structure of raw and thermal treated legume proteins: a Fourier transform infrared (FT-IR) spectroscopic study. Amino Acids, 43, pp. 911-921. doi:10.1007/ s00726-011-1151-4 tion (Kovalenko, Rippke and Hurburgh, 2006) or in vitro digestibility (Carbonaro, Maselli and Nucara, 2012).

Once comprehensive data on the different grain legume varieties is available and a clear picture of the overall nutritional high variability existing within each species defined, there will be many more opportunities to address protein deficiencies by incorporating grain legumes into nutrition and agriculture policies and by developing higher protein quality varieties through cross-breeding and selective breeding. These varieties would have higher protein content, but also higher protein quality. They will be better adjusted to animal and human requirements, have improved nutrient use efficiency, reduce dietary protein content and associated costs, and reduce nitrogen excretion that will decrease negative environmental impact.
Clarke, E. J. and Wiseman, J. (2000). Developments in plant breeding for improved nutritional quality of soya beans II. Anti-nutritional factors. The Journal of Agricultural Science, 134, pp. 125-136.

Cozzolino D. (2015). Foodomics and infrared spectroscopy: from compounds to functionality. Current Opinion in Food Science, 4, pp. 39-43. doi:10.1016/j.cofs.2015.05.003

Crepon, K., Marget, P., Peyronnet, C., Carrouee, B., Arese, P. and Duc, G. (2010). Nutritional value of faba bean (Vicia faba L.) seeds for feed and food. Field Crops Research, 115, pp. 329-339. doi:10.1016/j.fcr.2009.09.016

Devries, M. C. and Phillips, S. M. (2015). Supplemental protein in support of muscle mass and health: Advantage whey. Journal of Food Science, 80, pp. A8-A15. doi:10.1111/1750-3841.12802

Dinkins, R. D., Reddy, M. S. S., Meurer, C. A., Yan, B., Trick, H., Thibaud-Nissen, F., Finer, J. J., Parrott, W. A. and Collins, G. B. (2001). Increased sulfur amino acids in soybean plants overexpressing the maize $15 \mathrm{kDa}$ zein protein. In Vitro Cellular and Developmental Biology Plant, 37, pp. 742-747. doi:10.1079/ IVP2001205

Falco, S. C., Guida, T., Locke, M., Mauvais, J., Sanders, C., Ward, R. T. and Webber, P. (1995). Transgenic canola and soybean seeds with increased lysine. Nature Biotechnology, 13, pp. 577-582. doi:10.1038/nbt0695-577 
FAO (2013). Dietary protein quality evaluation in human nutrition. Report of an FAO Expert Consultation, Food and Nutrition Paper n.92. [On line]. Available from: http://www.fao.org/ag/humannutrition/nutrition/63158/en/.

Gatel, F. (1994). Protein quality of legume seed for non-ruminant animals: a literature review. Animal Feed Science and Technology, 45, pp. 317-348. doi:10.1016/0377-8401(94)90036-1

Gilani, G. S., Xiao, C. W. and Cockell, K. A. (2012). Impact of antinutritional factors in food proteins on the digestibility of protein and the bioavailability of amino acids and on protein quality. British Journal of Nutrition, 108, pp. S315-S332. doi:10.1017/ S0007114512002371

IFOAM (International Federation of Organic Agriculture Movement) (2014). The IFOAM norms for organic production and processing. Version 2014. Germany.

IYoP (International Year of Pulses) (2016). Action plan for the International Year of Pulses. (on the $3^{\text {rd }}$ March 2016). [On line] Available from: http://www.fao.org/pulses-2016/en/.

Islam, F. M. A., Rengifo, J., Redden, R. J., Basford, K. E. and Beebe, S. E. (2003). Association between seed coat polyphenolics (tannins) and disease resistance in common bean. Plant Foods for Human Nutrition, 58, pp. 285-297. doi: 10.1023/B:QUAL.0000040283.51023.c2

Kovalenko, I. V., Rippke, G. R. and Hurburgh, C. R. (2006). Determination of amino acid composition of soybeans (Glycine max) by Near-Infrared Spectroscopy. Journal of Agriculture and Food Chemistry, 54, pp. 3485-3491. doi: 10.1021/jf052570u

Messad, F., Létourneau-Montminy, M. P., Charbonneau, E., Sauvant, D. and Guay, F. (2015). Prediction of standardized ileal digestibility and essential amino acid content of ingredients in swine: A meta-analysis. Animal Feed Science and Technology, 207, pp. 204-221. doi:10.1016/j.anifeedsci.2015.06.012

Phelan, P., Moloney, A. P., McGeough, E. J., Humphreys, J., Bertilsson, J., O'Riordan E. G. and O'Kiely, P. (2015). Forage legumes for grazing and conserving in ruminant production systems. Critical
Reviews in Plant Sciences, 34, pp. 281-326. doi:10.1080/07352 689.2014.898455

Rumiyati, R., James, A. P. and Jayasena, V. (2012). Effect of germination on the nutritional and protein profile of Australian sweet lupin (Lupinus angustifolius L.). Food Nutritional Science, 3, pp. 621-626. doi:10.4236/fns.2012.35085

Schumacher, H., Paulsen, H. M., Gau, A. E., Link, W., Jurgens, H. U., Sass, O. and Dieterich, R. (2011). Seed protein amino acid composition of important local grain legumes Lupinus angustifolius L., Lupinus luteus L., Pisum sativum L. and Vicia faba L. Plant Breeding, 130, pp. 156-164. doi:10.1111/j.14390523.2010.01832.x

Ufaz, S. and Galili, G. (2008). Improving the content of essential amino acids in crop plants: Goals and opportunities. Plant Physiology, 147, pp. 954-961. doi:10.1104/pp.108.118091

Vaz Patto, M. C., Amarowicz, R., Aryee, A. N. A., Boye, J. I., Chung, H. J., Martín-Cabrejas, M. A. and Domoney, C. (2015). Achievements and challenges in improving the nutritional quality of food legumes. Critical Reviews in Plant Sciences, 34, pp. 105143. doi:10.1080/07352689.2014.897907

Wang, T. L., Domoney, C., Hedley, C. L., Casey, R. and Grusak, M. A. (2003). Can we improve the nutritional quality of legume seeds? Plant Physiology, 131, pp. 886-891. doi:10.1104/pp.102.017665

Warkentin, T. D., Delgerjava, O., Arganosaa, G., Rehmana, A. U., Betta, K. E., Anbessab, Y., Rossnagela, B. and Raboyc, V. (2012). Development and characterization of low-phytate pea. Crop Science, 52, pp. 74-78. doi:10.2135/cropsci2011.05.0285

WHO (World Health Organization) (2007). Protein and amino acid requirements in human nutrition. A report of a joint FAO/WHO/ UNU Expert Consultation. WHO technical report series, 935. Geneva, Switzerland: WHO Press.

Winkel-Shirley, B. (2002). Biosynthesis of flavonoids and effects of stress. Current Opinion in Plant Biology, 5, pp. 218-223. doi:10.1016/S1369-5266(02)00256-X 